\title{
THE IMPROVEMENT OF SKILL IN QUESTIONING THROUGH THE APPLICATION OF LEARNING STARTS WITH A QUESTION STRATEGY
}

\author{
Yuniarti, Sukarno, Sularmi \\ Universitas Sebelas Maret \\ yoniayo2@gmail.com
}

Article History

accepted 09/07/2018

approved 01/08/2018

published 17/09/2018

\section{Keywords}

strategi learning starts With a question (LSQ),

keterampilan bertanya

\begin{abstract}
The objectives of this research is to improve and describe the results of the improvement of questioning skills through the application of Learning Starts With a Question strategy in 5th grade students of SD Negeri Tegalayu No. 96 Surakarta. The subjects of this research are teachers and students of 5th grade of SD Negeri Tegalayu which are 20 students. The techniques of collecting data are in the form of test, observation, interview, and documentation. The data validity used is triangulation source and triangulation technique. The data analysis uses Miles and Huberman interactive analysis model. The results of this research indicate that the improvement of questioning skills through the application of Learning Starts With a Question strategy in each cycle is 70\% in cycle I it increases to 95\% in cycle II. The conclusion of this research is the application of Learning Starts With a Question strategy can improve the questioning skill of 5th grade students of Elementary School.
\end{abstract}

Social, Humanities, and Education Studies (SHEs): Conference Series https://jurnal.uns.ac.id/shes

p-ISSN 2620-9284

e-ISSN 2620-9292 


\section{PENDAHULUAN}

Pendidikan merupakan bagian terpenting dalam kehidupan manusia yang akan memberikan pengetahuan serta pemahaman tentang segala sesuatu yang dibutuhkan untuk dapat hidup dan berkembang dalam masyarakat. Pemahaman terhadap pengetahuan baru diperoleh melalui pembelajaran di sekolah dengan adanya interaksi antara guru, siswa dan sumber belajar. Pembelajaran menempatkan siswa sebagai subjek belajar yang secara aktif dapat membangun pengetahuannya sendiri berdasarkan pengalaman belajar yang telah diperoleh sebelumnya. Siswa mengaktualisasikan keterampilan dan bakat yang dimilikinya setelah menerima pengetahuan baru yang meliputi ranah kognitif, afektif, dan psikomotor. Pada proses pembelajaran, aktivitas bertanya sangat diperlukan. Sani (2017: 50) menjelaskan bahwa proses pembelajaran harus dilengkapi dengan aktivitas mengamati, menanya, mengolah, menyajikan, menyimpulkan, dan mencipta.

Bertanya dipandang sebagai salah satu bentuk kepedulian dan interaktif siswa dalam kegiatan pembelajaran. Suyadi (2013: 27) menjelaskan bahwa siswa yang bertanya bukan berarti tidak tahu sama sekali dan siswa yang diam tidak bertanya bukan pula berarti telah paham sepenuhnya, akan tetapi siswa yang aktif bertanya adalah siswa yang telah paham dan ingin memahami lebih lanjut atas penjelasan yang diberikan oleh guru. Bertanya tidak hanya membantu guru membuka wawasan siswa, namun juga membantu siswa menggali berbagai informasi dalam bentuk pengetahuan. Hosnan (2014: 48) mengemukakan bahwa salah satu kegiatan belajar adalah mengajukan pertanyaan tentang informasi yang tidak dipahami dari apa yang diamati untuk memperoleh informasi tambahan (dimulai dari faktual sampai ke pertanyaan yang bersifat hipotetik). Bertanya tidak hanya diungkapkan secara verbal saja. Suradji (2008: 21) mengemukakan bahwa pertanyaan lisan maupun tulisan merupakan alat untuk menimbulkan jawaban atau response.

Berdasarkan hasil wawancara yang dilakukan peneliti terhadap guru dan siswa, diperoleh informasi bahwa hanya 2 atau 3 dari 20 siswa yang aktif bertanya saat proses pembelajaran. Siswa belum dibiasakan untuk bertanya sehingga siswa merasa malu, takut, dan bingung ketika diminta untuk mengajukan pertanyaan. Siswa masih kesulitan merangkai kata-kata dengan tepat dalam bentuk kalimat tanya. Oleh karena itu, siswa lebih memilih bertanya kepada temannya daripada bertanya kepada guru. Selain melakukan wawancara, peneliti juga melakukan observasi dengan mengamati kegiatan pembelajaran IPS. Hasil observasi ditemukan bahwa pada saat diberikan kesempatan bertanya, tidak ada siswa yang berani bertanya dan mengemukakan pendapatnya mengenai materi yang telah dipelajari kepada guru. Siswa lebih memilih untuk diam sehingga guru sulit mengetahui pemahaman siswa terhadap materi yang telah dipelajari. Hasil wawancara dan observasi dibuktikan dengan hasil tes pratindakan. Siswa diminta menuliskan 6 pertanyaan berdasarkan materi yang telah disampaikan oleh guru. Hasil tes pratindakan menunjukkan bahwa terdapat 2 dari 20 siswa atau 10\% yang mendapat nilai dalam kategori terampil, 12 dari 20 siswa atau $60 \%$ mendapat nilai dalam kategori cukup terampil, 5 dari 20 siswa atau $25 \%$ mendapat nilai dalam kategori kurang terampil dan 1 dari 20 siswa atau 5\% mendapat nilai dalam kategori tidak terampil. Perolehan nilai rata-rata tes pratindakan keterampilan bertanya secara tertulis adalah 62,6. Hanya 2 dari 20 atau $10 \%$ siswa yang mendapat nilai dalam kategori terampil bertanya $(\geq 75)$ dan masih terdapat 18 atau $90 \%$ siswa yang belum terampil. Hal ini membuktikan bahwa keterampilan bertanya siswa kelas V SD Negeri Tegalayu No. 96 Surakarta masih tergolong rendah.

Penyebab rendahnya keterampilan bertanya siswa karena aktivitas siswa di kelas lebih banyak mencatat dan mendengarkan penjelasan guru daripada 
bertanya atau mengemukakan gagasannya. Peran siswa di kelas lebih sering sebagai penjawab daripada penanya. Siswa belum dibiasakan bertanya secara lisan maupun tulisan, sehingga ketika dilakukan tes pratindakan dengan menuliskan 6 pertanyaan banyak siswa yang membuat pertanyaan tanpa menggunakan kata tanya dan jenis pertanyaan yang diajukan siswa tersebut masih tergolong tingkat rendah (C1-C3). Siswa yang tidak dibiasakan untuk bertanya akan merasa malu, takut salah ataupun dianggap bodoh apabila ada dorongan dalam diri mereka untuk bertanya. Pola pikir demikian akan terus berlanjut kedepannya, padahal pertanyaan merupakan hal yang penting untuk membuka wawasan dan pengetahuan baru. Selain itu, kegiatan pembelajaran yang dilakukan guru belum berpusat pada siswa (student centered). Pembelajaran masih didominasi oleh penggunaaan metode ceramah sehingga belum sepenuhnya mampu mengaktifkan siswa. Hal ini menyebabkan siswa merasa bosan, jenuh, dan mengantuk sehingga siswa lebih memilih diam dan tidak merespons ketika diminta untuk bertanya. Kondisi tersebut menunjukkan bahwa tidak adanya perhatian dan ketertarikan siswa untuk menggali informasi lebih lanjut terhadap materi yang dipelajarinya. Siswa hanya menerima tanpa adanya keinginan untuk mencari tahu dan menyelidiki sendiri pengetahuan menggunakan seluruh potensi yang dimilikinya.

Mengacu pada permasalahan tersebut, maka harus ada upaya penangan yang tepat untuk mengatasi rendahnya keterampilan bertanya pada siswa kelas $\mathrm{V}$ SD Negeri Tegalayu. Salah satu upaya yang dapat dilakukan adalah dengan menerapkan strategi pembelajaran aktif Learning Starts With a Question. Silberman (2016: 157) menjelaskan bahwa Learning Starts With a Question merupakan strategi pembelajaran aktif yang menuntut siswa untuk menyelidiki dan mempelajari sendiri materi pelajaran sebelum diberi penjelasan oleh guru. Hal tersebut dapat menstimulasi peserta didik untuk mengajukan pertanyaan yang merupakan kunci belajar. Strategi ini memberikan kesempatan kepada siswa untuk menyelidiki, mencari tahu, memahami, dan memaknai bahan bacaan sebelum diminta untuk bertanya. Siswa menjadi lebih siap ketika diminta untuk bertanya karena sebelumnya telah diberikan kesempatan untuk membaca materi, sehingga mempunyai bahan untuk ditanyakan. Strategi ini melatih siswa untuk membangun sendiri pengetahuannya dengan cara mencari informasi secara mandiri dari bahan bacaan yang diberikan, sehingga siswa akan memperoleh infromasi dan pengetahuan baru yang tidak semuanya diperoleh dari penjelasan guru.

Berdasarkan uraian diatas, maka peneliti tertarik untuk melakukan penelitian dengan judul "Peningkatan Keterampilan Bertanya Melalui Penerapan Strategi Learning Starts With a Question (Penelitian Tindakan Kelas pada Siswa Kelas V SD Negeri Tegalayu No. 96 Surakarta Tahun Ajaran 2017/2018)". Rumusan masalah dalam penelitian ini adalah 1) apakah penerapan strategi Learning Starts With a Question dapat meningkatkan keterampilan bertanya pada siswa kelas V SD Negeri Tegalayu No. 96 Surakarta Tahun Ajaran $2017 / 2018$ ? 2) bagaimana hasil peningkatkan keterampilan bertanya siswa kelas V SD Negeri Tegalayu No. 96 Surakarta Tahun Ajaran 2017/2018 melalui penerapan strategi Learning Starts With a Question? Sesuai dengan rumusan masalah tersebut, penelitian ini bertujuan untuk 1) meningkatkan keterampilan bertanya melalui penerapan strategi Learning Starts With a Question pada siswa kelas V SD Negeri Tegalayu No. 96 Surakarta Tahun Ajaran 2017/2018. 2) mendeskripsikan hasil peningkatan keterampilan bertanya siswa kelas V SD Negeri Tegalayu No. 96 Surakarta Tahun Ajaran 2017/2018 melalui penerapan strategi Learning Starts With a Question. 


\section{METODE}

Penelitian ini merupakan Penelitian Tindakan Kelas (PTK) yang dilaksanakan di SD Negeri Tegalayu No. 96 Surakarta pada bulan Desember 2017-Juli 2018. Penelitian ini dilaksanakan dalam 2 siklus dan setiap siklus terdiri dari dua pertemuan. Setiap siklus terdiri dari 4 tahap, yaitu perencanaan, pelaksanaan, pengamatan, dan refleksi.

Subjek penelitian ini adalah guru dan siswa kelas V SD yang berjumlah 20 siswa, terdiri dari 11 siswa laki-laki dan 9 siswa perempuan. Data dalam penelitian ini berupa data kualitatif dan data kualitatif. Sumber data berasal dari guru, siswa, dan kegiatan pembelajaran.Teknik pengumpulan data berupa tes, observasi, wawancara, dan dokumentasi. Uji validitas data menggunakan triangulasi sumber dan triangulasi teknik.

Teknik analisis data yang digunakan dalam penelitian ini adalah model analisis interaktif Miles dan Huberman yang terdiri dari reduksi data, penyajian data, dan penarikan kesimpulan (Sugiyono, 2015: 337).

\section{HASIL DAN PEMBAHASAN}

Hasil penelitian yang dilaksanakan sebanyak 2 siklus dengan menerapkan strategi Learning Starts With a Question pada siswa kelas V SD Negeri Tegalayu No. 96 Surakarta menunjukkan adanya peningkatan keterampilan bertanya yang terjadi pada setiap siklus. Dari hasil analisis data, dapat diketahui peningkatan keterampilan bertanya yang cukup signifikan apabila dibandingkan dengan hasil pratindakan. Perbandingan nilai keterampilan bertanya pada pratindakan, siklus I dan siklus II setiap kategori dapat dilihat pada tabel 1. sebagai berikut.

Tabel 1. Perbandingan Nilai Keterampilan Bertanya pada Pratindakan, Siklus I, dan Siklus II setiap Kategori

\begin{tabular}{llcccc}
\hline & \multicolumn{2}{c}{ Kategori } & & Frekuensi & \\
\cline { 3 - 5 } Interval & & Pratindakan & Siklus I & Siklus II \\
$\leq 24$ & Tidak Terampil & (TT) & 1 & 0 & 0 \\
$25-49$ & Kurang Terampil (KT) & 5 & 0 & 0 \\
$50-74$ & Cukup Terampil & (CT) & 12 & 6 & 1 \\
$75-100$ & Terampil & (T) & 2 & 14 & 19 \\
\hline Jumlah & & 20 & 20 & 20 \\
\hline
\end{tabular}

Data yang terdapat pada tabel 1. diperjelas dalam bentuk grafik yang dapat dilihat pada gambar 1. berikut ini.

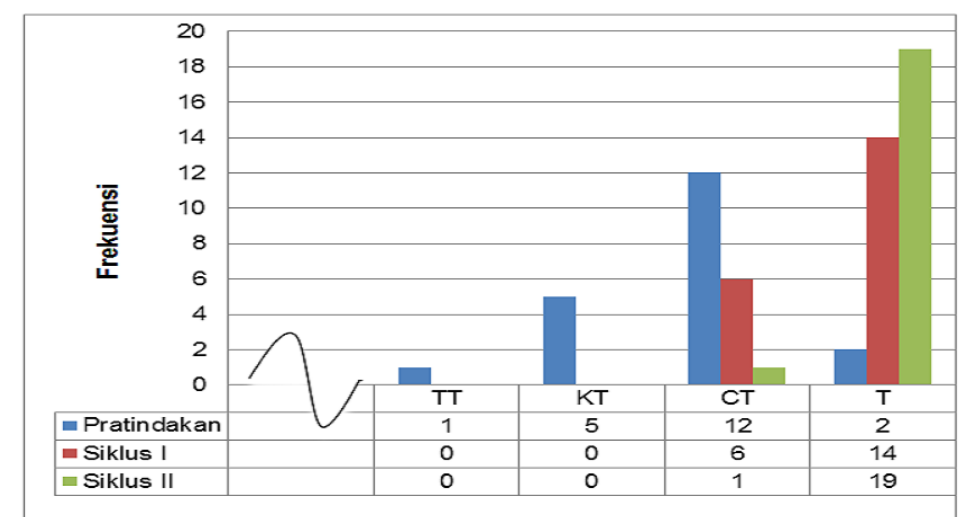

Gambar 1. Perbandingan Nilai Keterampilan Bertanya pada Pratindakan, Siklus I, dan Siklus II setiap Kategori 
Data pada tabel 1. dan gambar 1. menunjukkan adanya peningkatan keterampilan bertanya siswa yang terjadi pada setiap kategori. Pada pratindakan, terdapat $1(5 \%)$ siswa yang mendapat nilai dalam kategori tidak terampil, 5 (25\%) siswa mendapat nilai dalam kategori kurang terampil, 12 $(60 \%)$ siswa mendapat nilai dalam kategori cukup terampil dan $2(10 \%)$ siswa mendapat nilai dalam kategori terampil. Pada siklus I terjadi peningkatan pada setiap kategori yaitu $0(0 \%)$ siswa mendapat nilai dalam kategori tidak terampil, 0 $(0 \%)$ siswa mendapat nilai dalam kategori kurang terampil, $6(30 \%)$ siswa mendapat nilai dalam kategori cukup terampil dan 14 (70\%) siswa mendapat nilai dalam kategori terampil. Peningkatan keterampilan bertanya pada siklus II setiap kategori semakin baik dari sebelumnya yaitu $0(0 \%)$ siswa mendapat nilai dalam kategori tidak terampil, $0(0 \%)$ siswa mendapat nilai dalam kategori kurang terampil, $1(5 \%)$ siswa mendapat nilai dalam kategori cukup terampil dan 19 (95\%) siswa mendapat nilai dalam kategori terampil. Perbandingan nilai keterampilan bertanya pada pratindakan, siklus I, dan siklus II dapat dilihat dari peningkatan nilai rata-rata setiap indikator yang akan disajikan pada tabel 2 . sebagai berikut.

Tabel 2. Perbandingan Nilai Rata-rata Indikator Keterampilan Bertanya pada Pratindakan, Siklus I, dan Siklus II

\begin{tabular}{|c|c|c|c|c|}
\hline \multirow{2}{*}{ No } & \multirow{2}{*}{ Indikator } & \multicolumn{3}{|c|}{ Rata-rata Nilai } \\
\hline & & Pratindakan & Siklus I & Siklus II \\
\hline 1 & Singkat & 75,8 & 93,3 & 94,1 \\
\hline 2 & Jelas & 56,6 & 75,3 & 89,5 \\
\hline 3 & Relevan & 67,0 & 74,5 & 89,7 \\
\hline 4 & Jenis pertanyaan & 44,5 & 60,1 & 68,4 \\
\hline 5 & Ketepatan pertanyaan & 48,3 & 90,9 & 92,8 \\
\hline 6 & Penggunaan tanda tanya & 76,2 & 87,6 & 98,7 \\
\hline \multicolumn{2}{|c|}{ Rata-rata } & 61,4 & 80,2 & 88,8 \\
\hline
\end{tabular}

Perbandingan nilai rata-rata indikator keterampilan bertanya pratindakan, siklus I, dan siklus II dapat disajikan dalam bentuk grafik pada gambar 2. sebagai berikut.

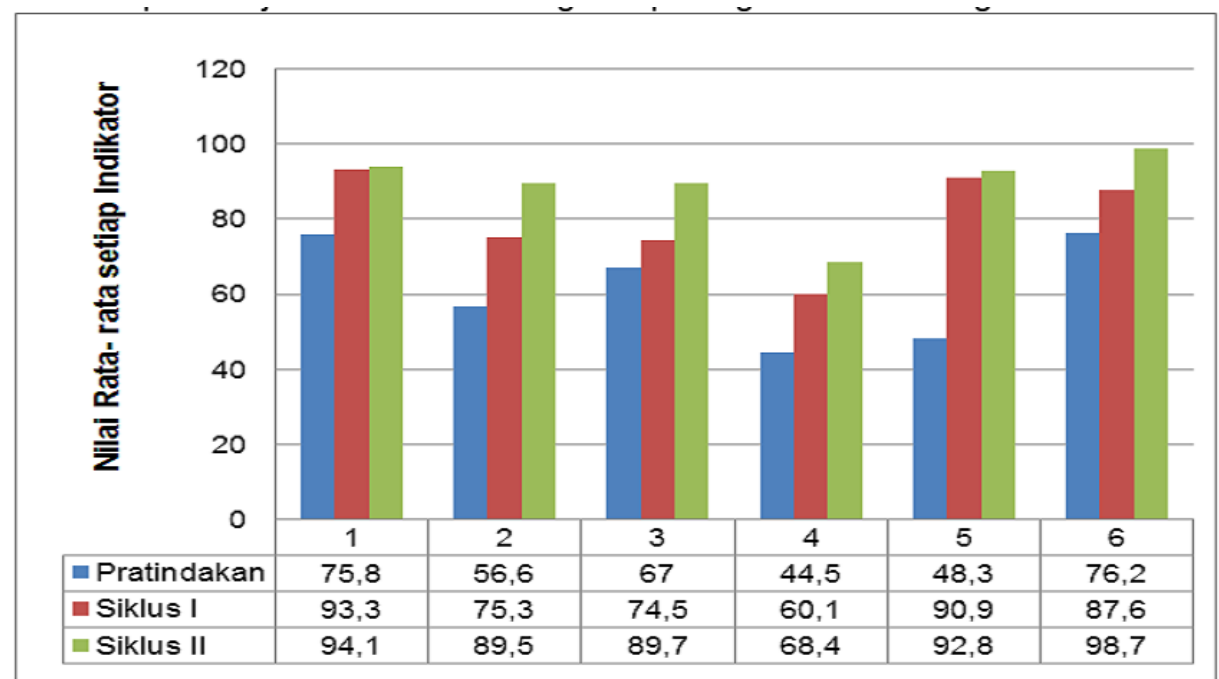

\section{Gambar 2. Perbandingan Nilai Rata-rata Indikator Keterampilan Bertanya pada Pratindakan, Siklus I, dan Siklus II}

Berdasarkan tabel 2. dan gambar 2. dapat dilihat perbandingan nilai rata-rata indikator keterampilan bertanya pratindakan, siklus I, dan siklus II selalu mengalami peningkatan. Peningkatan tersebut ditunjukkan dari perolehan nilai rata-rata indikator 
singkat pada pratindakan yaitu 75,8 meningkat menjadi 93,3 pada siklus I, dan pada siklus II meningkat lagi menjadi 94,1. Indikator jelas pada pratindakan yaitu 56,6 meningkat menjadi 75,3 pada siklus I, dan pada siklus II meningkat lagi menjadi 89,5 . Indikator relevan pada pratindakan memperoleh nilai rata-rata 67 meningkat menjadi 74,5 pada siklus I, dan pada siklus II meningkat menjadi 89,7. Indikator jenis pertanyaan pada pratindakan yaitu 44,5 meningkat menjadi 60,1 pada siklus I, dan pada siklus II meningkat lagi menjadi 68,4. Indikator ketepatan pertanyaan pada pratindakan memperoleh nilai rata-rata 48,3 meningkat menjadi 90,9 pada siklus I, dan pada siklus II meningkat menjadi 92,8. Indikator penggunaan tanda tanya pada pratindakan memperoleh nilai rata-rata 76,2 meningkat menjadi 87,6 pada siklus I, dan pada siklus II meningkat menjadi 98,7.

Berdasarkan hasil observasi terhadap penerapan strategi Learning Starts With a Question, peningkatan keterampilan bertanya terjadi karena penerapan strategi Learning Starts With a Question memberikan kesempatan kepada siswa untuk menyelidiki, mencari tahu, memahami, dan memaknai bahan bacaan sebelum diminta untuk bertanya melalui kegiatan membaca. Siswa menjadi lebih siap untuk bertanya karena mempunyai bahan untuk ditanyakan. Materi yang dijadikan sebagai bahan bacaan berbeda-beda disetiap pertemuan sehingga menumbuhkan rasa keingintahuan siswa untuk membaca dan menggali informasi lebih dalam melalui pertanyaan. Motivasi siswa meningkat akibat adanya kompetisi dalam diskusi untuk menjawab pertanyaan yang diajukan oleh kelompok lain. Siswa terlebih dulu dilatih bertanya secara lisan dan tulisan dalam bentuk kelompok kecil atau diskusi kelompok. Selanjutnya, siswa kembali dilatih untuk membuat 6 pertanyaan yang berbeda dari pertanyaan yang telah dibuat dalam kelompok. Hal ini memicu siswa untuk membuat pertanyaan yang lebih baik dari sebelumnya, sehingga skorskor yang diperoleh pun meningkat.

Persentase ketuntasan klasikal keterampilan bertanya pada pratindakan sebesar $10 \%$ atau 2 dari 20 siswa mendapat nilai dalam kategori terampil, meningkat pada siklus I menjadi $70 \%$ atau 14 dari 20 siswa mendapat nilai dalam kategori terampil, dan pada siklus II meningkat lagi menjadi 95\% atau 19 dari 20 siswa mendapat nilai dalam kategori terampil. Berdasarkan uraian diatas, ketuntasan klasikal keterampilan bertanya sudah melebihi indikator kinerja yang telah ditetapkan yaitu $80 \%$ atau 16 dari 20 siswa mendapat nilai dalam kategori terampil ( $\geq 75)$. Pencapaian indikator tersebut menunjukkan bahwa penerapan strategi Learning Starts With a Question telah berhasil meningkatkan keterampilan bertanya siswa kelas V SD Negeri Tegalayu No. 96 Surakarta Tahun Ajaran 2017/2018. Peningkatan keterampilan bertanya tersebut terjadi karena siswa selalu diberikan kesempatan untuk menyelidiki, mencari tahu, membaca, memahami, dan memaknai materi sebelum diminta untuk bertanya. Kebiasaan untuk bertanya dilatih melalui penerapan strategi Learning Starts With a Question dalam kegiatan diskusi kelompok kecil. Strategi ini dapat memicu keingintahuan siswa, sehingga mendorong siswa untuk bertanya pada guru maupun siswa lain. Hal ini sejalan dengan pendapat Zaini, dkk. (2008: 44) bahwa salah satu cara untuk membuat siswa belajar secara aktif dengan membuat siswa tersebut bertanya tentang materi pelajaran sebelum ada penjelasan dari guru. Pembelajaran dengan strategi Learning Starts With a Question memudahkan siswa untuk membuat pertanyaan karena langkah-langkah dalam strategi ini mendorong siswa berpikir kritis. Pernyataan ini diperkuat oleh pendapat Silberman (2016: 157) bahwa salah satu cara untuk menstimulasi siswa bertanya dengan menstimulir siswa untuk menyelidiki dan mempelajari sendiri materi pelajarannya tanpa penjelasan terlebih dahulu dari guru, sehingga siswa lebih siap mengajukan pertanyaan karena telah memiliki gambaran mengenai hal yang akan dipelajarinya. 


\section{SIMPULAN}

Berdasarkan hasil Penelitian Tindakan Kelas yang telah dilaksanakan sebanyak 2 siklus pada pembelajaran IPS, maka dapat disimpulkan bahwa penerapan strategi Learning Starts With a Question dapat meningkatkan keterampilan bertanya pada siswa kelas V SD Negeri Tegalayu No. 96 Surakarta Tahun Ajaran 2017/2018.

\section{DAFTAR PUSTAKA}

Hosnan, M. (2014). Pendekatan Saintifik dan Kontekstual dalam Pembelajaran Abad 21. Bogor: Ghalia Indonesia.

Sani, Ridwan, Abdullah. (2017). Pembelajaran Saintifik untuk Implementasi Kurikulum 2013. Jakarta: Bumi Aksara.

Silberman, Melvin, L. (2016). Active Learning: 101 Cara Belajar Siswa Aktif. Terj. Raisul Muttaqien. Bandung: Nuansa Cendekia. (Buku asli diterbitkan 1996).

Sugiyono. (2015). Metode Penelitian Pendidikan (Pendekatan Kuantitatif, Kualitatif,dan R\&D). Bandung: Alfabeta.

Suradji. (2008). Strategi Belajar Mengajar. Surakarta: UNS Press.

Suyadi. (2013). Strategi Pembelajaran Pendidikan Karakter. Bandung: PT Remaja Rosdakarya.

Zaini, Hisyam., Bermawy Munthe., dan Sekar Ayu Aryani. (2008). Strategi Pembelajaran Aktif. Yogyakarta: Pustaka Insan Madani. 